\title{
Column
}

\section{Schuivende panelen in Schotse voorstellen}

\section{Luc van Zutphen}

De Schotten zijn altijd al een krachtig en voortvarend volk geweest. Over kracht gesproken, de Romeinen beheersten eeuwenlang het grootste gedeelte van Europa en de landen rondom de Middellandse Zee, maar bij de Schotse Hooglanden eindigde hun territorium. De vestingmuur van Hadrianus - ten dele bemand met soldaten uit onze streken - moest ervoor zorgen dat de 'wilde volken uit het Noorden' de Pax Romana niet zouden verstoren. Voortvarendheid is ook een opvallend kenmerk; de eerste accountantsvereniging in de wereld was de Society of Accountants in Edinburgh, opgericht in 1853 en een jaar later in het trotse bezit van het Royal Charter. De basis voor de ontwikkeling van het hedendaagse accountantsberoep werd in Schotland gelegd.

Die rol als voortrekker wil het tegenwoordige Institute of Chartered Accountants of Scotland nog steeds vervullen.

In 1991 besloot dit instituut een commissie onder leiding van Prof. lan Percey opnieuw te laten onderzoeken hoe de inmiddels in accountantskringen beruchte verwachtingskloof op de meest effectieve manier in de toekomst zou kunnen worden gereduceerd. Let wel: gereduceerd en niet overbrugd of gedempt. De probleemstelling getuigt in dit opzicht van realiteitszin. Het zal altijd wel zo blijven dat gebruikers van accountantsdiensten meer van de accountant verwachten dan hij kan leveren. Het resultaat van deze studie was een discussierapport dat in 1993 werd gepubliceerd onder de toekomstgerichte titel 'Auditing into the Twenty-First Century'.
Evenals vele van haar voorgangers - onder meer Macdonald, Treadway en Cadbury - onderzocht ook de Schotse commissie welke percepties en verlangens er bij de belanghebbenden onder het publiek bestaan ten aanzien van de onafhankelijkheid, de verantwoordelijkheden en de eventuele wettelijke aansprakelijkheid van openbare accountants.

In het studierapport worden de volgende indringende vragen behandeld:

1 Welke waarborgen verlangt het publiek in onze tijd van het werk van de accountant?

2 Welke opvattingen leven er bij het publiek over de onafhankelijkheid, verantwoordelijkheid en aansprakelijkheid van de accountant?

3 Aan welke verlangens kan de accountant in redelijkheid voldoen?

Als antwoord op de eerste vraag neemt de commissie waar dat het publiek van de externe accountant verwacht dat hij een cruciale rol vervult bij de bescherming van de belangen van aandeelhouders, crediteuren, gepensioneerden, werknemers en het algemene publiek. In de taal van 'the man in the street' moeten accountants mede waarborgen dat:

1 de jaarrekening een juist beeld geeft;

2 er geen faillissement dreigt;

3 er geen fraude is gepleegd;

4 het bedrijf voldoet aan wettelijke voorschriften;

5 er deskundig is bestuurd;

Prof. L.C. van Zutphen, registeraccountant, is hoogleraar Accountantscontrole aan de Vrije Universiteit te Amsterdam. Lid van de Orde van Organisatiekundigen en -Adviseurs. Voorzitter van het Limperg Instituut. 
6 er verantwoord is omgegaan met milieu- en andere maatschappelijke problemen.

In een gedegen hoofdstuk wordt elk van deze zes 'public expectations' onderzocht op redelijkheid en haalbaarheid.

Interessant is om te lezen hoe de commissie het redelijkheidscriterium formuleert

De basisgedachte daarbij is puur economisch van aard. Een verwachting wordt redelijk en haalbaar geacht indien er belanghebbenden zijn die voor de dienst willen betalen. met andere woorden er is sprake van een effectieve vraag.

Maar tevens moet iemand bereid zijn deze dienst te verlenen - voor een prijs die mede gerelateerd is aan het eraan verbonden risico - en die bovendien beschikt over de vereiste deskundigheid.

Zowel voor het management als voor de externe accountant wordt vervolgens uitvoerig beargumenteerd in welke mate aan de hierboven genoemde verlangens redelijkerwijs zou kunnen worden voldaan.

Er wordt gepleit voor het opnemen van een 'Statement of Director's Responsibilities' waarin dit toporgaan zijn verantwoordelijkheden ten aanzien van de zes punten uiteenzet.

De leidende gedachte daarbij is dat aan het publiek meer informatie en grotere waarborgen moeten worden verschaft en dat de effectiviteit van de audiffunctie moet worden opgevoerd. Als het aan de commissie ligt dan verschuiven op enkele plaatsen toch duidelijk de panelen.

Heel markant blikt dit als we kennisnemen van het in het rapport opgenomen voorbeeld van de accountantsverklaring van de toekomst, die overigens wordt omgedoopt tot de verklaring van assessoren.

Kijkend naar de oordeelsparagraaf dan wordt door de accountants van de toekomst vastgesteld dat.

het management informatiesystemen en interne controle systemen heeft ontwikkeld en onderhouden die voldoende betrouwbaar zijn om informatie te verschaffen die kan leiden tot waarheidsgetrouwe financiële overzichten: deze systemen ook van een zodanige kwaliteit zijn dat de mogelijkheden van fraude en andere onwettige handelingen tot een minimum worden beperkt:

de gepubliceerde jaarrekening een getrouw beeld geeft van de financiële positie en het resultaat en dat terzake aan de wettelijke voorschriften is voldaan:

de jaarrekening is opgesteld op basis van het terechte oordeel van het management dat er voldoende financieringsmiddelen beschikbaar zijn om de continuiteit van het bedriff voor ten minste de komende 12 maanden te waarborgen.

De projectie van een dergelijke verklaring op de zes punten leidt tot de volgende observaties. Duidelijk is dat in de toekomst de oude en beproefde verklaring van getrouwheid een gewild produkt blift.

De management audit wordt overigens vierkant afgewezen; volgens de commissie behoort de beoordeling van de bestuurders tot de taak van commissarissen.

Bijzonder is wel de met een tijdbepaling aangescherpte continuiteitsclausule: deze komt wel dicht in de buurt van een garantie.

Het meest opvallend is echter de uitbreiding van zowel de verslaggeving als de accountantscontrole tot het management informatiesysteem en de business controls.

Beide systemen zijn - als ze goed werken machtige instrumenten om de betrouwbaarheid van de interne informatieverzorging en de externe verslaggeving op het vereiste peil te houden. Maar dat niet alleen. Ook bij het minimaliseren van frauderisico's en het naleven van de voor het bedriff relevante regelgeving spelen deze systemen een cruciale rol. Zo vindt de commissie dat het interne controle systeem ook moet verzekeren dat het bedrijf zijn bij de wet geregelde maatschappelijke verplichtingen nakomt. zoals bijvoorbeeld de milieuwetgeving. En wat te denken van onderwerpen als de fiscale wetgeving. de arbeidsomstandigheden, de bestrijding van computercriminaliteit of specifieke brancheregels? 
Hoe realistisch is eigenlijk de toekomstvisie van onze Schotse collega's? Zijn de voorstellen reëel en is de invoering ervan aanstaande? Als we de recente ontwikkelingen in eigen land en over de grenzen bezien dan is de toekomst eigenlijk al begonnen. Onlangs heeft het $\mathrm{ka}$ binet een wetsvoorstel ingediend waarbij bedrijven die een grote milieubelasting veroorzaken, zullen worden verplicht om een milieuverslag te publiceren.

In de Verenigde Staten wordt al door een toenemend aantal grotere bedrijven door het management gerapporteerd over de kwaliteit van het interne controle systeem, met een duidelijke referentie naar de verklaring van de externe accountant. In het Engelse Cadbury-rapport wordt eenzelfde gedragslijn voorgestaan.
Het is de hoogste tijd om over deze ontwikkelingen ook in ons land verder na te denken. De gevolgen en mogelijkheden voor het accountantsberoep zijn belangrijk en uitdagend. Zowel voor kantoren, diensten, de beroepsorganisaties als voor de individuele accountant. Ook opleiding en onderzoek kan daarbij een actieve rol worden toebedacht.

En bij dit alles betekent het Schotse rapport een flinke duw in de rug en wat mij betreft in de goede richting.

\section{Noot}

1 Auditing into the Twenty-First Century. The Institute of Chartered Accountants of Scotland, Edinburgh 1993 